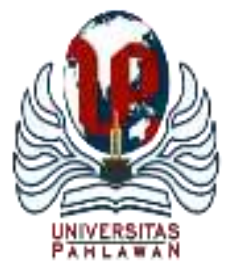

Edukatif : Jurnal Ilmu Pendidikan Volume 4 Nomor 1 Tahun 2022 Halm 539 - 547

EDUKATIF: JURNAL ILMU PENDIDIKAN

Research \& Learning in Education

https:/ledukatif.org/index.php/edukatif/index

\title{
Penerapan Pendekatan Reciprocal Teaching dalam Meningkatkan Hasil Belajar Ilmu Pengetahuan Sosial Siswa Sekolah Menengah Pertama
}

\author{
Jamaluddin Arifin ${ }^{1 凶}$, Andi Fitriani. $\mathbf{M}^{2}$ \\ Universitas Muhammadiyah Makassar, Indonesia ${ }^{1}$ \\ SMA 1 Bambaira Pasangkayu, Indonesia ${ }^{2}$ \\ E-mail : jamaluddinarifin@unismuh.ac.id ${ }^{1}$, andi.fitriani022@gmail.com ${ }^{2}$
}

\begin{abstract}
Abstrak
Penerapan pendekatan pembejaran merupakan bagian integral untuk menunjang keberhasilan belajar siswa, tetapi sejauh ini, guru belum mahir dalam menerapkan pendekatan yang sesuai dengan karakteristik materi ajar di dalam proses pembelajaran di ruang kelas, akibatnya siswa belum sepenuhnya mampu memperoleh nilai maksimal di dalam proses pembelajaran, termasuk di dalam proses pembelajaran IPS. Penelitian ini bertujuan untuk meningkatkan hasil belajar siswa kelas IX pada mata pelajaran IPS di SMP Negeri 1 Pallangga Kabupaten Gowa melalui pendekatan Reciprocal Teaching. Penelitian ini dikategorisasi ke dalam jenis penelitian tindakan kelas yang melibatkan siswa kelas IX SMP Negeri 1 Pallangga Kabupaten Gowa sebagai subjek penelitian. Hasil penelitian ini menunjukkan bahwa penerapan pendekatan reciprocal teaching memberikan dampak yang cukup signifikan terhadap peningkatan hasil belajar IPS siswa. Pada siklus I persentase ketuntasan 46,43\% yaitu 13 orang yang tuntas dari 28 siswa dan meningkat pada siklus II dengan persentase ketuntasan 85,71\% yaitu 24 orang yang tuntas dari 28 siswa. Nilai rata - rata pada siklus I yaitu 60,61 meningkat pada siklus II menjadi 80. Temuan penelitian ini memiliki implikasi penting bagi guru untuk menerapkan pendekatan reciprocal teaching dalam meningkatkan hasil belajar IPS siswa SMP.
\end{abstract}

Kata Kunci: reciprocal teaching, hasil belajar, classroom action research

\begin{abstract}
The application of the learning approach is an integral part of supporting the learning success of students, but so far, teachers have not been proficient in applying approaches that are in line with the characteristics of teaching materials in the learning process in the classroom, as a result, students have not been fully able to obtain maximum value in the learning process, including in the social studies learning process. This study aims to improve the learning outcomes of class IX students in social studies subjects at SMP Negeri 1 Pallangga, Gowa Regency through a Reciprocal Teaching approach. This research is categorized into classroom action research, the study involved students of class IX SMP Negeri 1 Pallangga, Gowa Regency as research subjects. The results of this study indicate that the application of the reciprocal teaching approach has a significant impact on improving students' social studies learning outcomes. In the first cycle, the percentage of completeness was 46.43\%, namely 13 people who completed from 28 students, and increased in the second cycle with the percentage of completeness $85.71 \%$, namely 24 people who completed from 28 students. The average value in the first cycle is 60.61, increasing in the second cycle to 80. The findings of this study have important implications for teachers to apply a reciprocal teaching approach in improving social studies learning outcomes for junior high school students.
\end{abstract}

Keywords: reciprocal teaching, learning outcomes, classroom action research

Copyright (c) 2022 Jamaluddin Arifin, Andi Fitriani. M

$\triangle$ Corresponding author:

Email : jamaluddinarifin@unismuh.ac.id

DOI : https://doi.org/10.31004/edukatif.v4i1.1807

ISSN 2656-8063 (Media Cetak)

ISSN 2656-8071 (Media Online)

Edukatif : Jurnal Ilmu Pendidikan Vol 4 No 1 Tahun 2022

p-ISSN 2656-8063 e-ISSN 2656-8071 
540 Penerapan Pendekatan Reciprocal Teaching dalam Meningkatkan Hasil Belajar Ilmu Pengetahuan Sosial Siswa Sekolah Menengah Pertama - Jamaluddin Arifin, Andi Fitriani. M

DOI: https://doi.org/10.31004/edukatif.v4i1.1807

\section{PENDAHULUAN}

Penerapan pendekatan pembelajaran merupakan bagian integral yang dapat menunjang keberhasilan belajar siswa. Dengan pendekatan pembelajaran, siswa dapat memaksimalkan potensi belajar mereka untuk tumbuh dan berkembang pada bidang studi tertentu (Entwistle \& McCune, 2004), karena siswa mempunyai minat dan daya tarik terhadap mata pelajaran yang diajarkan di sekolah (Pramitha Putri, 2021). Dengan kata lain, pemilihan pendekatan pembelajaran yang sesuai dengan karkateristik materi ajar yang akan disajikan atau dipaparkan guru di ruang-ruang kelas akan berdampak positif terhadap prestasi belajar siswa. Proses belajar dan hasil belajar siswa akan meningkat, karena pendekatan pembelajaran yang digunakan oleh guru dapat mendorong siswa untuk berperan aktif dalam proses belajar mereka (E. Aflalo, 2012; Hasnor et al., 2013; Pramitha Putri, 2021; Wegner et al., 2021). Singkatnya, pendekatan pembejaran yang tepat memiliki dampak terhadap prestasi hasil belajar siswa. Ini karena siswa menjadi lebih mudah untuk mengetahui dan memahami muatan materi ajar secara efektif (Abdullah, 2017; Wahid \& Amarwanti, 2015). Karena itu, pengetahuan guru terhadap penggunaan pendekatan pembelajaran pada materi ajar tertentu sangat penting untuk membantu siswa mereka dalam mencapai hasil belajar yang memadai.

Peningkatan hasil belajar siswa pada materi ajar tertentu dapat dicapai melalui penerapan pendekatan pembelajaran (Liana \& Hamzah, 2022). Namun sejauh ini, optimalimasi penerapan pendekatan pembelajaran dalam proses belajar-mengajar guru di ruang-ruang kelas belum cukup memadai. Ester Aflalo \& Gabay (2013) menunjukkan bahwa pengetahuan dan kesadaran guru terhadap penggunaan pendekatan pembejaran belum diperoleh secara maksimal. Hal ini dapat dibuktikan dari proses belajar-mengajar yang dilakukan oleh guru. Guru masih menjadi pusat pembelajaran. Dengan perkataan lain, paradigma proses belajar-mengajar yang mengharapkan siswa seabagi pusat pembejaran (students centered) belum sepenuhnya terealisasi di sekolah (Muliarta, 2018). Guru belum mengoptimalkan proses belajar-mengajar mereka dengan menggunakan pendekatan pembelajaran. Akibatnya, hasil belajar siswa pada mata pelajaran tertentu cenderung masih jauh dari kata 'tuntas'.

Kriteria ketuntasan minimal (KKM) pada mata pelajaran tertentu belum diperoleh secara maksimal oleh keseluruhan siswa di berbagai jenjang pendidikan. Hal ini terjadi karena guru belum memiliki pengetahuan dalam memilah dan memilih pendekatan pembelajaran yang sesuai dengan karakteristik materi ajar yang akan diajarkan. Kondisi semacam ini, misalnya, ditemukan di SMP Negeri 1 Palangga, Kabupaten Gowa. Dari hasil observasi yang dilakukan peneliti di sekolah tersebut ditemukan bahwa guru belum mengatahui beragam pendakatan pembelajaran. Selain itu, mereka juga kurang dalam menggunakan pendekatan pembelajaran yang sesuai dengan materi ajar yang akan disajikan. Pada mata pelajaran IPS, misalnya, guru masih menyajikan materi dengan menggunakan metedo ceramah. Dengan perkataan lain, proses belajar-mengajar yang dibangun guru di dalam ruang kelas tidak mengarahkan siswa mereka untuk berperan aktif dalam proses pembelajaran IPS. Akibatnya, siswa dalam proses pembelajaran hanya sebagai pembelajar yang pasif, bukan sebagai pembelajar yang aktif atau menjadi pusat pembelajaran (students centered learning) (Muliarta, 2018).

Pendekatan pembelajaran terbalik (reciprocal teaching) merupakan salah satu pendekatan pembelajaran yang dapat menodorong siswa untuk belajar mandiri, kreatif, dan lebih aktif dalam proses pembelajaran IPS. Reciprocal teaching adalah pendekatan yang berdasar pada prinsip-prinsip pembuatan/pengajuan pertanyaan, dimana keterampilan-keterampilan metakognitif (merangkum, meringkas, mengklarifikasi dan memprediksi) diajarkan melalui pengajaran langsung dan pemodelan oleh guru untuk penampilan murid terhadap materi pelajaran. Dalam proses pembejaran IPS, reciprocal teaching dapat mendorong siswa untuk berperan sebagai guru dalam menyampaikan materi kepada teman-temannya. Sementara itu, guru lebih berperan sebagai model yang menjadi fasilitator dan pembimbing yang melakukan scaffolding (Fajarwati, 2010, p. 17; McAllum, 2014; Slavin, 2011, p. 14; Suyatno, 2009, p. 64). Pendekatan pembelajaran reciprocal teaching dalam 
pembelajaran IPS dapat memberikan kesempatan yang luas bagi siswa untuk berperan aktif dalam proses pembejaran. Karena itu, pendekatan pembelajaran ini dipandang relevan serta memungkinkan dapat membantu dalam mengatasi persoalan yang dihadapi oleh guru terkait hasil belajar IPS di SMP Negeri 1 Palangga, Kabupaten Gowa, yang masih rendah.

Penelitian terkait reciprocal teaching sudah pernah dilakukan oleh beberapa peneliti sebelumnya. Sahab (2014) misalanya, menunjukkan bahwa pendekatan reciprocal teaching memiliki banyak manfaat dalam pengajaran membaca, seperti membantu siswa untuk memahami teks dengan mudah dan mendorong siswa agar lebih aktif dalam berkomunikasi. Sementara itu, penelitian Ahmadi \& Gilakjani (2012) menunjukkan bahwa pengajaran reciprocal teaching memiliki efek positif yang signifikan pada pemahaman membaca bahasa Inggris dan penggunaan empat strategi membaca metakognitif utama siswa EFL. Sementara itu, penelitian Wanhar (2020) menunjukkan bahwa reciprocal teaching berpengaruh positif dalam meningkatkan hasil belajar IPS siswa kelas IV SD Kecamatan Percut Sei Tuan Kabupaten Deli Serdang. Penelitian ini dengan beberapa penelitian sebelumnya itu memiliki persamaan dan perbedaan. Persamaanya ialah samasama menggunakan reciprocal teaching. Sementara itu, perbedaannya terletak pada subjek penelitian dan sasaran materi ajar atau mata pelajaran yang akan dikemas dengan menggunakan pendekatan reciprocal teaching. Penelitian ini menggunakan reciprocal teaching untuk mata pelajaran IPS. Karena penelitian ini memiliki perbedaan dengan penelitian sebelumnya, maka penelitian ini memiliki nilai kontribusi penting untuk mengisi kesenjangan penelitian berkaitan dengan penerapan pendekatan reciprocal teaching dalam konteks pembelajaran IPS di SMP.

\section{METODE PENELITIAN}

Jenis penelitian yang digunakan dalam penelitian ini ialah penelitian tindakan kelas (Classroom Action Research). Jenis penelitian ini dipilih karena sesuai dengan karakteristik penelitian ini yaitu, untuk meningkatkan hasil belajar IPS melalui penggunaan pendekatan reciprocal teaching. Pelaksanaan penelitian ini dibagi ke dalam dua siklus. Hal ini seperti yang dikemukakan oleh Arikunto, (2008) dan Cahyani et al., (2021) bahwa pelaksanaan penelitian tindakan kelas biasanya dilakukan dengan membagi dua siklus. Setiap siklus dalam penelitian ini terdiri atas empat tahapan, yaitu (a) perencanaan tindakan, (b) pelaksanaan tindakan, (c) observasi dan evaluasi, dan (d) analisis dan refleksi. Penelitian ini dilaksanakan di SMP Negeri 1 Pallangga Kabupaten Gowa. Sementara itu, partisipan atau subjek dalam penelitian ini ialah siswa kelas IX SMP Negeri 1 Pallangga Kabupaten Gowa. Adapun teknik pengumpulan data dalam penelitian ini menggunakan teknik tes dan lembar observasi. Teknik tes digunakan untuk mengetahui hasil belajar IPS siswa, sedangkan lembar observasi digunakan untuk mengetahui keaktifan pendekatan reciprocal teaching dalam proses pembelajaran IPS. Data dalam penelitian ini dianalisis secara deskriptif dengan menggunakan kriteria ditetapkan oleh Departemen Pendidikan dan Kebudayaan (Arikunto, 2008; Mashita, 2018), sebagai berikut.

Tabel 1

Teknik Kategori Standar Berdasarkan Ketetapan Departemen Pendidikan Nasional

\begin{tabular}{cc}
\hline Skor & Kategori \\
\hline $0-34$ & Sangat rendah \\
$35-54$ & Rendah \\
$55-64$ & Sedang \\
$65-84$ & Tinggi \\
$85-100$ & Sangat tinggi \\
\hline
\end{tabular}

Indikator keberhasilan pembelajaran IPS dalam penelitian ini diklasifikasi ke dalam dua kategori. Pertama, indikator keberhasilan yang berkaitan dengan peningkatan hasil belajar IPS siswa minimal $75 \%$ telah memperoleh nilai minimal 65. Kedua, indikator keberhasilan yang berkaitan dengan proses pelaksanaan pembelajaran yaitu minimal 75\% skenario pembelajaran yang dibuat telah dilaksanakan dengan benar. 
542 Penerapan Pendekatan Reciprocal Teaching dalam Meningkatkan Hasil Belajar Ilmu Pengetahuan Sosial Siswa Sekolah Menengah Pertama - Jamaluddin Arifin, Andi Fitriani. M

DOI: https://doi.org/10.31004/edukatif.v4i1.1807

\section{HASIL DAN PEMBAHASAN PENELITIAN}

Proses pengambilan data penlitian ini yang menggunkan tahapan sesuai dengan kaidah penelitian tindakana kelas melalui pendekatan reciprocal teaching terjadi peningkatan hasil belajar IPS pada siswa kelas IX SMP Negeri I Pallangga Kabupaten Gowa. Penelitian Tindakan Kelas ini menggunakan 2 Siklus, setiap siklus dilaksanakan 4 kali pertemuan setiap pertemuan keempat diadakan evaluasi. Siklus I menguraikan materi tentang perjuangan melawan penjajah, siklus II menguraikan materi tentang usaha mempersiapkan dan mempertahankan kemerdekaan Republik Indonesia. Berikut penelasan singkat pelaksanaan penelitian ini:

\section{Siklus I}

Tindakan siklus I dilaksanakan 4 kali pertemuan, pada awal bulan Juni sampai pertengahan bulan Juni 2021. Adapun tahapan-tahapan yang dilakukan pada siklus I dapat dijabarkan sebagai berikut:

1. Tahap Perencanaan

Lie, (2002, p. 62) mengemukakan bahwa sebelum pelaksanaan tindakan, dilakukan persiapan pelaksanaan pembelajaran dengan materi tentang perjuangan melawan penjajah dengan menerapkan pendekatan reciprocal teaching sebagai berikut :

a. Menelaah kurikulum tingkat satuan pendidikan (KTSP) tahun 2006 sedemikian rupa sehingga pokok bahasan dapat diajarkan selama 3 kali pertemuan.

b. Membuat skenario pembelajaran untuk setiap pertemuan.

c. Membuat format observasi untuk melihat bagaimana kondisi siswa pada saat proses belajar mengajar berlangsung selama diadakan tindakan.

d. Merancang dan membuat kisi - kisi soal, serta soal sebagai alat evaluasi.

2. Tahap Pelaksanaan

Dalam tahapan ini guru melaksanakan pembelajaran sesuai dengan rencana pembelajaran yang telah disusun sebelumnya. Berikut ini tahapan - tahapan yang dilakukan sebagai berikut :

a. Pertemuan I

Pertemuan I dilaksanakan pembelajaran dengan menerapkan pendekatan reciprocal teaching. Pembelajaran dimulai dengan mengucapkan salam dan berdo'a sebelum belajar dan mengabsen siswa, mengapersepsi siswa dan guru memberikan motivasi kepada siswa agar lebih semangat mengikuti pelajaran. Dan menyampaikan tujuan pembelajaran BPUPKI pada siswa. Lie, (2002, p. 60) mengemukakan langkah pertama yang dilakukan pada pendekatan reciprocal teaching yaitu guru menyajikan pelajaran tentang" persiapan kemerdekaan melalui badan penyelidik usaha-usaha persiapan kemerdekan Indonesia (BPUPKI), diantaranya menjelaskan tentang tokoh - tokoh yang terlibat dalam usaha persiapan kemerdekaan serta tujuan dibentuk dan diselenggarakannya BPUPKI. Guru mengajak siswa untuk menyimpulkan materi, selanjutnya pada akhir pembelajaran siswa diberikan PR yang dilanjutkan penyampaian pesan-pesan moral dan pembelajaran diakhiri dengan doa yang dipimpin oleh ketua kelas.

b. Pertemuan II

Pertemuan II dilaksanakan pembelajaran direncanakan dengan menerapkan pendekatan reciprocal teaching. Guru membuka proses pembelajaran ini diawali dengan mengucapkan salam dan berdoa sebelum belajar, dan dilanjutkan dengan guru mengabsen serta melakukan apersepsi tentang materi sebelumnya yang berkaitan dengan materi yang akan dipelajari. Apersepsi tersebut membahas tentang BPUPKI. Selanjutnya guru memotivasi siswa, yang dilanjutkan dengan menyampaikan tujuan pembelajaran yaitu untuk mengetahuai sidang pertama dan kedua BPUPKI serta tokoh-tokoh yang terlibat dalam BPUPKI. Selanjutnya memasuki inti pembelajaran. Menurut Lie, (2002, p. 60) mengemukakan langkah pertama yang dilakukan pada model pendekatan reciprocal teaching yaitu guru menyampaikan materi tentang sidang pertama dan kedua BPUPKI serta tokoh-tokoh yang terlibat dalam BPUPKI. Setelah itu guru mulai membagikan LKS untuk dikerjakan dan siswa yang telah selesai jawabannya dikumpulkan, setelah itu guru dan siswa bersama- 
sama menyimpulkan pembelajaran. Guru memberikan PR untuk dikerjakan dirumah dan dilanjutkan pemberian pesan-pesan moral agar sepulang sekolah pelajaran yang telah dipelajari tadi di sekolah dipelajari kembali di rumah dan pembelajaran ditutup dengan doa dan salam.

c. Pertemuan III

Pertemuan III dilaksanakan pembelajaran direncanakan dengan menerapkan pendekatan reciprocal teaching. Guru membuka proses pembelajaran ini diawali dengan mengucapkan salam, membaca doa, dan mengabsen siswa. Setelah itu guru melakukan apersepsi dan bertanya tentang pelajaran lalu yang telah dipelajari yaitu isi gagasan dari 3 tokoh tentang dasar Negara Indonesia. Selanjutnya guru menyampaikan tujuan pembelajaran yaitu untuk mengetahui tentang persiapan kemerdekaan melalui panitia persiapan kemerdekaan indonesia (PPKI). Selanjutnya, menurut Lie, (2002, p. 60) mengemukakan langkah pertama yang dilakukan pada pendekatan reciprocal teaching yaitu guru menyampaikan materi pembelajaran tentang tokoh-tokoh dalam usaha persiapan kemerdekaan yang dilakukan PPKI dan menjelaskan tugas PPKI. Setelah siswa selesai mengerjakan siswa menyampaikan hasil kerjanya secara bergantian, dan meminta tanggapan kepada teman yang lainnya apakah hasil jawaban yang sampaikan benar atau salah. Setelah itu jawaban yang salah diperbaiki bersama-sama. Selanjutnya, siswa diberikan tugas yaitu mengerjakan LKS, setelah selesai dikumpulkan oleh guru. Setelah itu pemberian pesan-pesan moral dan diakhiri dengan salam.

d. Pertemuan IV

Pertemuan IV ini dimulai dengan mengevaluasi hasil kerja siswa setiap pertemuan, setelah itu siswa diberikan lembar soal untuk tes akhir pada siklus I.

\section{Tahap Observasi}

Pada tahapan ini peneliti melakukan pengamatan selama proses pembelajaran IPS berlangsung dengan menggunakan lembar observasi. Observasi ini dilakukan untuk mengetahui seberapa besar keaktifan siswa SMP Negeri 1 Pallangga Kabupaten Gowa dalam proses pembelajaran. Adapun hasil observasi menunjukkan hasil belajar Ilmu Pengetahuan Sosial (IPS) setelah diterapkan pendekatan reciprocal teaching pada siklus I adalah jumlah siswa yaitu 28 orang, skor ideal yang dapat dicapai yaitu 100 dengan nilai maksimum yang diperoleh siswa yaitu 95 dan skor minimum yaitu 40 dengan rentang skor 55 dengan nilai rata-rata 61,65. Dari skor rata-rata tersebut menunjukkan bahwa hasil belajar IPS siswa kelas IX SMP Negeri 1 Pallangga Kabupaten Gowa pada siklus I sebesar 61,60 hal ini disebabkan karena masih kurangnya perhatian siswa dengan melakukan kegiatan lain selama proses pembelajaran berlangsung.

\section{Refleksi}

Berdasarkan hasil dari pengamatan selama proses pembelajaran pada siklus I pelaksanaan tindakan belum mencapai indikator keberhasilan yang telah ditetapkan yakni $75 \%$ dari jumlah siswa mendapatkan nilai $\geq 65$. Hal ini dapat dilihat pada pelaksanaan tindakan pada siklus I yang masih jauh dari yang diharapkan. Menurut pengamatan observer, peneliti tidak menyampaikan tujuan pembelajaran, peneliti pada saat memulai pelajaran kurang memotivasi siswa sehingga siswa belajar kurang terarah.

\section{Siklus II}

Tindakan siklus II sama seperti pada tindakan siklus I yaitu dilaksanakan 4 kali pertemuan. Masing masing pertemuan adalah 3 x 35 menit. Pelaksanaan pembelajaran siklus II dilaksanakan empat kali pertemuan. Adapun tahapan-tahapan yang dilakukan pada siklus II adalah sebagai berikut:

\section{Tahap Perencanaan}

Berdasarkan hasil observasi, evaluasi, dan refleksi pelaksanaan tindakan siklus I belum mencapai target indikator keberhasilan penelitian yang ditentukan oleh peneliti, sehingga peneliti bersama guru dan teman sejawat secara berkolaborasi merencanakan tindakan pada siklus II. Pada kegiatan perencanaan ini guru menyusun Rencana Pelaksanaan Pembelajaran (RPP), menyiapkan materi pembelajaran tentang perjuangan melawan penjajahan dalam mempersiapkan dan mempertahankan kemerdekaan RI termasuk instrumen dan 
544 Penerapan Pendekatan Reciprocal Teaching dalam Meningkatkan Hasil Belajar Ilmu Pengetahuan Sosial Siswa Sekolah Menengah Pertama - Jamaluddin Arifin, Andi Fitriani. M

DOI: https://doi.org/10.31004/edukatif.v4i1.1807

lembar observasi yang akan digunakan untuk pertemuan berikutnya. Peneliti menyiapkan lembar pelatihan persepsi dan lembar observasi.

2. Tahap Pelaksanaan

Adapun proses pembelajaran pada tahap pelaksanaan ini meliputi beberapa hal sesuai dengan rencana pelaksanaan pembelajaran yang telah disusun sebelumnya, sebagai berikut :

a. Pertemuan I

Pertemuan I guru mengawali pembelajaran dengan berdo'a bersama dan mengabsen siswa. Seperti pada pertemuan sebelumnya, guru melakukan apersepsi dengan menanyakan pelajaran yang telah dipelajari. Siswa dengan berebutan menjawab pertanyaan yang diberikan oleh guru. Setelah itu, menurut Lie, (2002, p. 60) mengemukakan langkah pertama yang dilakukan pada pendekatan reciprocal teaching yaitu guru menyampaikan tujuan dan kompetensi yang akan dicapai, selanjutnya guru menjelaskan materi yaitu dengan mengajak siswa untuk mengamati dan mengidentifikasi gambar tokoh dalam mempersiapkan kemerdekaan Indonesia. Hasil pekerjaan disampaikan dan teman-teman lainnya menanggapi jawaban yang dibacakan oleh temannya. Setelah selesai pekerjaan dikumpulkan guru terlebih dahulu memberikan motivasi setelah itu diakhiri dengan salam dan doa setelah belajar.

b. Pertemuan II

Pertemuan II proses pembelajaran diawali dengan berdoa bersama dan mengabsen siswa. Setelah itu guru melakukan apersepsi dengan menanyakan pelajaran yang telah dipelajari kemarin. Selanjutnya mengarahkan siswa untuk membuka buku IPS dan melanjutkan materi tentang "detik-detik proklamasi". Lie, (2002, p. 60) mengemukakan langkah pertama yang dilakukan pada pendekatan reciprocal teaching yaitu guru mulai menjelaskan materi tentang peristiwa menjelang proklamasi secara umum, dan setelah itu guru bertanya jawab tentang materi yang belum dimengerti.selanjutnya siswa dibagikan lembar kerja untuk dikerjakan.siswa yang selesai kemudian jawabannya dikumpulkan. Selanjutnya guru memberikan pertanyaan kepada siswa untuk mengetahui sejauh mana siswa mengerti tentang materi tentang detik - detik proklamasi. Dan memberikan pesan-pesan moral untuk berhati hati di jalan dan mengulang kembali pelajarannya jika sampai dirumah. Pelajaran diakhiri dengan doa.

\section{c. Pertemuan III}

Pertemuan ke III dilaksanakan dengan guru membuka pembelajaran dengan memberi salam, meminta siswa membaca doa belajar, dan mengabsen. Setelah itu guru menanyakan kabar siswa dan meminta masingmasing siswa mengumpulkan pekerjaan rumahnya. Selanjutnya guru menghubungkan pembelajaran yang lalu dengan yang akan dipelajari selanjutnya dengan menyampaikan tujuan pembelajaran. Selanjutnya, menurut Lie, (2002, p. 60) mengemukakan langkah pertama yang dilakukan pada pendekatan reciprocal teaching yaitu guru mulai menjelaskan materi proses terjadinya perumusan negara. Selanjutnya membahas bersama tugas yang diberikan dan dilanjutkan mengerjakan LKS. Diakhiri pembelajaran guru dan siswa menyimpulkan pembelajaran dan memberikan pesan-pesan moral dan berdoa bersama sebelum pulang.

d. Pertemuan IV

Pertemuan ke IV dilaksanakan dengan mengevaluasi hasil belajar siswa melalui lembar kerja soal.

\section{Tahap Observasi}

Seperti pada siklus I, peneliti kembali melakukan pengamatan selama proses pembelajaran IPS dengan menggunakan lembar observasi. Secara umum hasil observasi dan evaluasi terjadi peningkatan dibandingkan dengan siklus I.

4. Refleksi

Hasil observasi dan evaluasi pelaksanaan tindakan siklus II ini sudah lebih baik dari siklus I. Hasil observasi dan evaluasi pada pelaksanaan tindakan siklus II ini menunjukkan adanya peningkatan dari hasil belajar siswa yang signifikan karena proses pembelajaran telah berjalan dengan baik sesuai dengan yang 
direncanakan, Sepenuhnya mencapai target indikator keberhasilan penelitian yang peneliti tetapkan yakni $75 \%$ siswa harus memperoleh nilai $\geq 65$. Dengan demikian, nilai rata-rata siswa mengalami peningkatan dari 61,60 menjadi 80 dan telah berada di atas nilai KKM, sehingga penelitian ini dapat dikatakan berhasil. Berhasilnya pembelajaran IPS pada siswa kelas IX SMP Negeri I Pallangga Kabupaten Gowa dapat dilihat melalui:

a. Persentase kehadiran siswa pada siklus I dan siklus II sebesar $100 \%$

b. Persentase siswa yang memperhatikan penjelasan guru sebesar $55,99 \%$ dan meningkat menjadi $84,53 \%$.

c. Persentase siswa yang mampu membaca materi dengan baik dan benar sebesar 59,52\% meningkat pada siklus II menjadi 96,43\%.

d. Persentase siswa yang berani bertanya tentang materi yang belum dipahami pada siklus I sebesar 46,43\% meningkat pada siklus II menjadi 78,57\%.

e. Persentase siswa yang menyajikan hasil kerjanya pada siklus I sebesar $60,71 \%$ meningkat menjadi $89,29 \%$ pada siklus II.

f. Persentase siswa yang menyimpulkan materi pembelajaran sebesar $47,62 \%$ meningkat menjadi $75 \%$.

Setelah melihat analisis hasil belajar siswa setelah pelaksanaan siklus I dan siklus II diketahui bahwa terjadi peningkatan hasil belajar IPS siswa kelas IX SMP Negeri I Pallangga Kabupetn Gowa setelah menerapkan pendekatan reciprocal teaching, dapat dilihat pada tabel berikut.

Tabel 2

Gambaran Peningkatan Hasil Belajar IPS Siswa Kelas IX SMP Negeri 1 Pallangga Kabupaten Gowa

\begin{tabular}{llllllll}
\hline \multirow{2}{*}{ No } & \multirow{2}{*}{ Siklus } & \multirow{2}{*}{ Subjek } & Skor & & & & \multirow{2}{*}{ Rentang Skor } \\
\cline { 4 - 7 } & & & Ideal & Maksimum & Minimum & Rata-rata & \\
\hline 1 & Siklus I & 28 & 100 & 95 & 40 & 61,60 & 55 \\
\hline 2 & Siklus II & 28 & 100 & 100 & 50 & 80 & 50 \\
\hline
\end{tabular}

Tabel 1.2 di atas menunjukkan bahwa terjadi peningkatan hasil belajar IPS siswa kelas IX SMP Negeri I Pallangga Kabupetn Gowa dari siklus I ke siklus II. Hal ini menunjukkan bahwa pendekatan reciprocal teaching memiliki implikasi penting dalam membangkitkan minat siswa terhadap materi pelajaran IPS. Dengan kata lain, implementasi reciprocal teaching pada materi pelajaran IPS membuat mata pelajaran itu menjadi menarik, bervariasi, dan menghibur siswa. Hal ini seperti dikemukakan oleh Ahmadi \& Gilakjani (2012) dan Sahab (2014) bahwa pendekatan timbal balik (reciprocal teaching) mengacu pada kegiatan instruksional yang berlangsung dalam bentuk dialog antara guru dan siswa mengenai segmen teks, sehingga siswa menjadi pusat pembelajaran.

Hasil penelitian ini menguatkan argumentasi Cahyani et al., (2021) bahwa agar siswa dapat belajar dengan baik, model mengajar harus diusahakan yang tepat, efisien, dan seefisien mungkin, karena model mengajar dapat mempengaruhi belajar siswa. Pendapat yang senanda juga dikemukakan oleh Liana \& Hamzah (2022) bahwa pembelajaran kooperatif tidak hanya unggul dalam membantu siswa memahami konsep yang sulit, tetapi juga sangat berguna untuk menumbuhkan kemampuan berpikir kritis, bekerjasama, dan membantu teman. Di sini dapat disimpulkan bahwa penerapan pendekatan reciprocal teaching dalam pembelajaran IPS pada siswa kelas IX SMP negeri 1 Pallangga Kabupaten Gowa memberikan dampak yang cukup signifikan terhadap peningkatan hasil belajar IPS siswa.

\section{KESIMPULAN}

Berdasarkan hasil penelitian yang diperoleh dalam upaya peningkatan hasil belajar IPS siswa kelas IX SMP Negeri 1 Pallangga Kabupaten Gowa, diperoleh kesimpulan bahwa aktivitas belajar siswa mengalami peningkatan dengan penerapan pendekatan reciprocal teaching. Hal ini tampak dari proses pembelajaran siswa yang terekam dari siklus I ke siklus II. Pada siklus I tampak bahwa siswa masih banyak yang cenderung pasif, bermalas-malasan, dan kurang memperhatikan penjelasan yang diberikan oleh guru. Akan tetapi, pada pembelajaran siklus II, setelah diterapkan pendekatan reciprocal teaching, aktivitas siswa mulai terlihat aktif, 
546 Penerapan Pendekatan Reciprocal Teaching dalam Meningkatkan Hasil Belajar Ilmu Pengetahuan Sosial Siswa Sekolah Menengah Pertama - Jamaluddin Arifin, Andi Fitriani. M

DOI: https://doi.org/10.31004/edukatif.v4i1.1807

senang, dan serius terhadap materi ataupun tugas yang diberikan oleh guru IPS mereka. Di samping itu, penerapan pendekatan reciprocal teaching dalam proses pembelajaran IPS siswa kelas IX SMP Negeri 1 Pallangga Kabupaten Gowa mengalami peningkatan hasil belajar dari siklus I ke II. Peningkatan hasil belajar itu terjadi karena guru dalam penerapan pendekatan reciprocal teaching dalam pembelajaran IPS memberikan empat strategi pemahaman, yaitu meringkas, menanya, memprediksi, dan mengklarifikasi. Keempat strategi itu dikemas oleh guru IPS melalui diskusi kelompok terbimbing sehingga siswa merasa nyaman dengan proses dan strategi yang diberikan oleh guru. Penerapan reciprocal teaching dalam proses pembelajaran IPS, dengan secara bertahap memberdayakan siswa untuk mengambil peran guru. Karena itu, siswa cenderung memiliki penguasaan materi dengan baik, karena proses belajar mereka di dalam kelas bertumpu pada siswa, atau siswa sebagai pembelajar yang aktif atau menjadi pusat pembelajaran (students centered learning).

\section{DAFTAR PUSTAKA}

Abdullah. (2017). Pendekatan dan Model Pembelajaran yang Mengaktifkan Siswa. Edureligia, 01(01), 45-62.

Aflalo, E. (2012). Learning approach and learning strengths : a case study in an ultraorthodox community. Issues in Educational Research, 22(3), 201-212. https://doi.org/10.3316/aeipt.195496

Aflalo, Ester, \& Gabay, E. (2013). Learning Approach and Learning: Exploring a New Technological Learning System. International Journal for the Scholarship of Teaching and Learning, 7(1). https://doi.org/10.20429/ijsotl.2013.070114

Ahmadi, M. R., \& Gilakjani, A. P. (2012). Reciprocal teaching strategies and their impacts on English reading comprehension. Theory and Practice in Language Studies, 2(10), 2053-2060. https://doi.org/10.4304/tpls.2.10.2053-2060

Arikunto, S. (2008). Prosedur Penelitian Suatu Pendekatan Praktik. Rineka Karya.

Cahyani, H. D., Hadiyanti, A. H. D., \& Saptoro, A. (2021). Peningkatan Sikap Kedisiplinan dan Kemampuan Berpikir Kritis Siswa dengan Penerapan Model Pembelajaran Problem Based Learning. Edukatif: Jurnal Ilmu Pendidikan, 3(3), 919-927. https://edukatif.org/index.php/edukatif/article/view/472/pdf

Entwistle, N., \& McCune, V. (2004). The Conceptual Bases of Study Strategy Inventories. Educational Psychology Review, 16(December), 325-345. https://doi.org/https://doi.org/10.1007/s10648-004-0003-0

Fajarwati, M. S. (2010). Penerapan Model Reciprocal Teaching Sebagai Upaya Meningkatkan Pemahaman Konsep Matematika Siswa Kelas XI Akuntansi RSBI (Rintisan Sekolah Bertaraf Internasional) Di Smk Negeri 1 Depok. Universitas Negeri Yogyakarta.

Hasnor, H. N., Ahmad, Z., \& Nordin, N. (2013). The Relationship between Learning Approaches and Academic Achievement Among Intec Students, Uitm Shah Alam. Procedia - Social and Behavioral Sciences, 90(InCULT 2012), 178-186. https://doi.org/10.1016/j.sbspro.2013.07.080

Liana, M., \& Hamzah, S. (2022). Edukatif: Jurnal Ilmu Pendidikan Upaya Meningkatkan Hasil Belajar Teknologi Jaringan Berbasis Luas ( WAN ) melalui Penerapan Model Pembelajaran Project Based Learning Mengunakan Aplikasi QR-Code. 4(1), 316-322.

Lie, A. (2002). (2002). Cooperative Learning. Grasindo.

Mashita, M. (2018). Implementasi Teknik Pemodelan Untuk Meningkatkan Keterampilan Membaca Puisi Pada Siswa Kelas II SDN 006 Sekip Hulu Rengat. Jurnal Pendidikan Tambusai, 2(5), 1048-1068.

McAllum, R. (2014). Reciprocal Teaching: Critical Reflection on Practice. Kairaranga, 15(1), 26-35.

Muliarta, I. K. (2018). Menerjemahkan Perubahan Dari TCL (Teacher Center Learning) Ke SCL (Student Center Learning). Cetta: Jurnal Ilmu Pendidikan, 1(2), 76-86. file:///C:/Users/User/Downloads/49Article Text-95-1-10-20190108.pdf

Pramitha Putri, H. (2021). Edukatif: Jurnal Ilmu Pendidikan Pengaruh Media Pembelajaran Power Point 
547 Penerapan Pendekatan Reciprocal Teaching dalam Meningkatkan Hasil Belajar Ilmu Pengetahuan Sosial Siswa Sekolah Menengah Pertama - Jamaluddin Arifin, Andi Fitriani. M

DOI: https://doi.org/10.31004/edukatif.v4i1.1807

Interaktif terhadap Hasil Belajar IPS Siswa Sekolah Dasar. Edukatif: Jurnal Ilmu Pendidikan, 3(6), 3538-3543. https://doi.org/10.31004/edukatif.v3i6.986

Sahab, M. R. (2014). The Use Of Reciprocal Teaching Procedure In Teaching Narrative Texts To Improve Students' Reading Comprehension. Journal of English and Education, 2(2), 1-8.

Slavin, R. E. (2011). Psikologi Pendidikan (Teori dan Praktik). Indeks.

Suyatno. (2009). Menjelajah Pembelajaran Inofatif. Masmedia Buana Pusaka.

Wahid, A., \& Amarwanti, D. (2015). Keefektifan Metode PQRST (Preview, Question, Read, Summerize, Test) dalam Membaca Pemahaman Teks Bacaan pada Mata Pelajaran Bahasa Indonesia Kelas VII SMP Negeri 1 Bontomatene Kabupaten Kepulauan Selayar. Jurnal Konfiks, 2(2), 103-108. https://doi.org/https://doi.org/10.26618/jk.v2i2.410

Wanhar, F. A. (2020). Pengaruh model pembelajaran reciprocal berbantuan media it terhadap hasil belajar ips siswa kelas iv sd negeri 101777 saentis. Jurnal Ilmiah Maksitek, 5(3), 17-22.

Wegner, C., Minnaert, L., \& Strehlke, F. (2021). The importance of learning strategies and how the project 'Kolumbus-Kids' promotes them successfully. European Journal of Science and Mathematics Education, 1(3), 137-143. https://doi.org/10.30935/scimath/9393 